\title{
Evaluating the Corporate Social Responsibility Disclosure of Nigeria's Most Profitable Companies
}

\author{
Abass Olabode Samuel a ${ }^{\text {iD }}$, Umaru Mustapha Zubairu a ${ }^{\text {iD }}$, Bilkisu Abubakar ${ }^{\text {b }}$ iD \\ ${ }^{a}$ Federal University of Technology Minna, Niger State, Nigeria \\ ${ }^{b}$ Baze University, Abuja, Nigeria
}

\section{APA Citation:}

Samuel, A.O., Zubairu, U. M. \& Abubakar, B. (2020). Evaluating the corporate social responsibility disclosure of Nigeria's most profitable companies. TIJAB (The International Journal of Applied Business), 4(2), 106-115.

Submission Date: 08/06/2020

Acceptance Date: 09/11/2020

\begin{abstract}
This study evaluated Corporate Social Responsibility (CSR) disclosure in the most profitable companies in Nigeria, a review was carried out on the annual reports and websites of the five most profitable companies in Nigeria according to the market cap list 2018. This research focused on the quantity and quality of CSR disclosures, provided by these companies. The method of analysis used was content analysis. The result of this study revealed that from the three dimensions constituting Community disclosure, Environmental disclosure and Human Resource disclosure, Community disclosure was the most disclosed dimension from the top profitable companies in Nigeria. Findings revealed that these companies disclosed a lot about the different CSR activities they had undertaken within the span of one year, but the quality of these disclosures were relatively low. CSR disclosure should be encouraged by the Nigerian government by publicly recognizing companies who disclose CSR activity, this will motivate other companies to practice and disclose CSR.
\end{abstract}

Keywords: corporate social responsibility, community disclosure, environmental disclosure, human resource disclosure, Nigeria.

This is an open access article under the $\mathrm{CCBY-NC-SA}$ license.

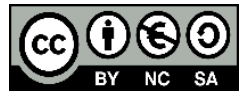

\section{Introduction}

Over the last few decades, the issue of corporate social responsibility (CSR) has transitioned from something companies did out of a sense of charity to something absolutely crucial to business survival as stakeholders demand more than just goods and services from these companies (Nurleni \& Bandang, 2018). The concept of triple bottom line where companies have to concern themselves with profits,

\footnotetext{
${ }^{1}$ Corresponding author.

E-mail address: uzubairu@gmail.com
} 
people and planet has become the global standard for any business that wants to thrive in an increasing competitive global business environment (Weidner et al., 2020).

CSR constitutes the commitment shown by companies to contribute to the economic and social development of the society. The essence of embarking on CSR by companies should not be to make profit but rather to give back to the society as a result of the fact that such businesses have benefited from the society either through the use of its resources or patronage of its citizens (Reverte, 2016). A company is able to provide evidence to interested stakeholders of its commitment to helping society through CSR disclosures in its annual reports or dedicated CSR reports (Cho et al., 2015). These CSR disclosures tends to boost the reputation of the company because when its annual report reveals that it is socially responsible, stakeholders hold the company with high esteem (Beck et al., 2018). Stakeholders use CSR information to ascertain whether a company is a good corporate citizen (Bhatia \& Chander, 2014).

Over the years, a stream of CSR research has sought to determine the CSR performance of companies by analyzing the quantity and quality of CSR disclosures from these companies' annual reports (Noronha et al., 2015: Lawal et al, 2017; Hoang et al., 2018). This study aims to contribute to this body of research by exploring the quantity and quality of Nigerian's most profitable companies.

In an ideal world, the role of government is to provide a conducive environment whereby its citizens can enjoy the highest quality of life (Farook et al., 2011). Such a society would be one where citizens are able to take for granted such basic infrastructure such as potable water, motorable highways and roads, affordable and accessible health-care and perhaps most importantly security of life and property (Lawal et al, 2017). However, in Nigeria, the reality is far from this ideal scenario. Over the years, Nigerian citizens have suffered from poor infrastructure, lack of electricity, poor education, and lack of security of life and property (Omotoso et al., 2020). As a result of the inability or unwillingness of the Nigerian government to provide these basic needs for its citizens, the responsibility has now been shifted to private companies who are prospering from the patronage of these citizens (Ali et al., 2017).

A social contract exists between these companies and their customers, in that the customers expect these companies to give back to the community in exchange for their continued patronage of their products and services; this social contract is particularly strong amongst Nigeria's most profitable companies (Dangote Cement, Nestle Nigeria Plc, Guarantee Trust Bank, Nigerian Breweries and Zenith Bank) (Omotoso et al., 2020). This study sought to examine to what extent Nigeria's top five most profitable companies are fulfilling their social contract with the Nigerian people by investigating the quality and quantity of their CSR disclosures as outlined in their annual reports and website (Alotaibi \& Hussainey., 2016).

\section{Literature Review}

\subsection{Social contract theory}

Social contract theory was propounded by Thomas Hobbes in 1651 (Bhatia \& Chander, 2014). Thomas Hobbes was an English philosopher, considered to be one of the founders of modern political philosophy (Etieyibo \& Omiegbe, 2020). Social Contract theory describes society as 'a series of social contracts between people living in the society and society itself' (Etieyibo \& Omiegbe, 2020). In other words, an organisation should act in a responsible manner not because it is in its commercial interest, but because it is part of how society expects organisations to operate (Roelofs, 2020). Noronha et al. (2015) used this theory to investigate CSR disclosure in Chinese railway companies which was a corporate response after a major train accident. 
In the context of this study, the social contract theory posits that Nigerian citizens patronize the five most profitable companies on a regular basis and therefore these companies have a social obligation to give back to the society by performing certain responsibilities through corporate social responsibility. Figure 1 provides the theoretical frame work of this study based on the social contact theory.

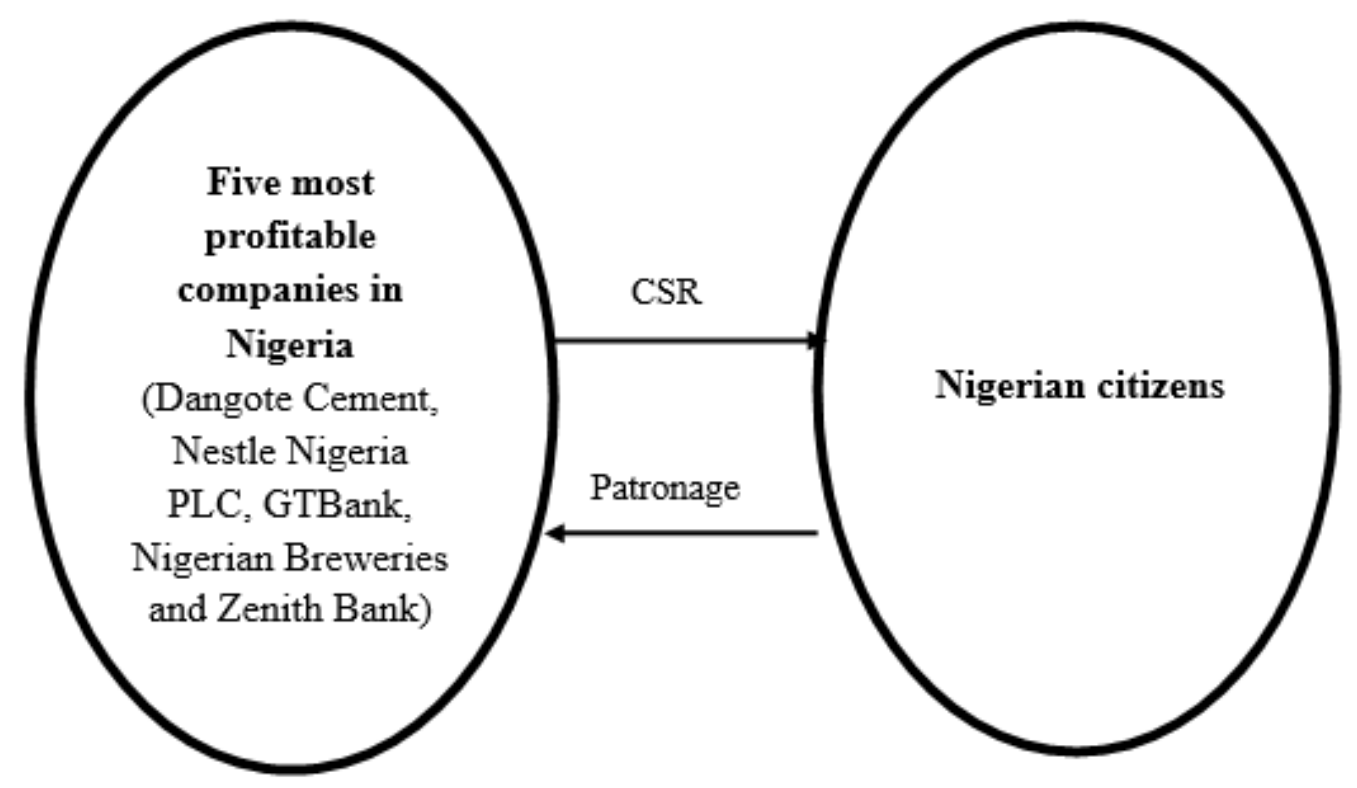

Figure 1. Theoretical framework of study based on social contract theory

\section{2. $\quad$ CSR disclosures}

A review of prior studies that evaluated the CSR disclosures of companies revealed that a majority of these studies focused primarily on the quantity of disclosures provided in company annual reports (e.g., Bhatia \& Chander, 2014; Cahan et al., 2016; Ali et al., 2017; Nurleni \& Bandang, 2018; Wasiuzzaman \& Wan Mohammad, 2020). Other studies focused on the quality of CSR disclosures provided by companies (e.g., Chauvey et al., 2015; Noronha et al., 2015; Muttakin \& Subramaniam, 2015). Only a small minority of studies reviewed combined both quantity and quality of disclosures when investigating the CSR disclosure of companies (e.g., Alotaibi \& Hussainey, 2016; Appuhami \&Tashakor, 2017). This represents a research gap in the extant CSR disclosure literature which this study sought to address by evaluating the quantity and quality of CSR disclosures by Nigeria's five most profitable companies. This provides a more holistic appraisal of the level of CSR performed by these companies.

A geographical and sample gap was also identified after a review of empirical CSR disclosure studies. None of the studies reviewed took place in a Nigerian context and thus did not include any Nigerian companies. The Nigerian business climate is a peculiar one due to challenges of corruption and weak regulation (Amodu, 2017). This study provides an insight into how CSR activities are practiced and disclosed within this unique business environment.

A third research gap was the fact that previous CSR disclosure studies tended to rely almost exclusively on company annual reports when evaluating the CSR disclosures of companies (e.g., Noronha et al., 2015; Barakat et al, 2015). This study improves the quality and quantity of CSR disclosure data collected by including the websites of the five Nigerian companies under consideration. 
Websites have been identified as a rich source of CSR disclosure data (Hassan \& Batool, 2016; Sharma, 2020).

\section{Method}

\subsection{Sample / Participants}

The population in this study consisted of all registered companies in Nigeria, which according to the Corporate Affairs Commission was 3.1 million as of March 2018 there were 3.1 million (Corporate Affairs Commission, 2020). According to the social contract theory of CSR, companies that benefit the most from the members of society have the most responsibility to give back to that society. For this reason, this study adopted a purposive sampling technique by focusing on the top five most profitable companies in Nigeria. According to the marketing capitalization ranking, as of 2018, the following were the most profitable companies in Nigeria, Dangote cement, Nestle Nigeria Plc, Guarantee Trust Bank, Nigerian Breweries and Zenith Bank (Olakoyenikan, 2019).

\subsection{Data collection and analysis}

Data for this study was collected from the 2018 annual reports of the five Nigerian companies under consideration as well as their official company websites. All pages of the annual reports were read and every page of the website as well in order to identify all mentions of CSR activities carried out by the companies in 2018. The three researchers read these data sources independently and to determine the quantity and quality of CSR disclosures for each company compared and discussed their findings until a consensus was achieved.

As mentioned in the introductory section of this paper, this main aim of this study was to assess the quantity and quality of CSR disclosures by Nigeria's five most profitable companies. The selected companies' annual report for 2018 and websites In order to reveal the quantity of CSR disclosures, CSR activities amongst these companies were itemized to help provide the number of CSR activities disclosed under each of the categories constituting Community, Environment or Human Resource disclosures (Stahl et al., 2020).

The quality of each CSR disclosure was assessed based on three criteria: 1) Listing of the CSR activity, 2) Disclosure of the monetary amount spent on the itemized CSR activity, and 3) Pictorial evidence of the itemized CSR activity (Bouten et al., 2011). A CSR disclosure that met only one of the criteria was labeled as "low quality"; one that met two of the criteria was labeled as "moderate quality", while one that met all three criteria was labeled as "high quality". Table 1 provides additional insight as to how quality of disclosures was determined.

Table 1. Criteria for assessing quality of CSR disclosures

\begin{tabular}{cc}
\hline Number of criteria disclosed & Quality status \\
\hline 1 & Low \\
2 & Moderate \\
3 & High \\
\hline
\end{tabular}

Each company would then be assigned an overall total quality score which would be calculated by adding the individual quality scores and dividing by the total number of CSR disclosures made by the company. Table 2 presents an illustration. Assume a company had disclosed five CSR activities in their annual reports. For the first (CSR 1) and fifth (CSR 5) activities, it only listed the information without providing monetary information or pictorial evidence; this leads to a low quality score of "1". For CSR 
2 and CSR 3, it provided information of two of the three quality criteria thus earning a score of " 2 " and for CSR it provided all three criteria thus earning a quality score of " 3 ".

Table 2. Illustration of "Quality score" calculation for a company

\begin{tabular}{ccc}
\hline S/N & CSR Activities & Quality Score \\
1 & CSR 1 & 1 \\
2 & CSR 2 & 2 \\
3 & CSR 3 & 3 \\
4 & CSR 4 & 2 \\
5 & CSR 5 & 1 \\
& Aggregate Quality Score & 9 \\
\hline
\end{tabular}

Source: Authors

Quality score of company = Aggregate quality score/Number of CSR activities

$$
\begin{gathered}
=9 / 5 \\
=1.80
\end{gathered}
$$

This method of analysis helps determine the quantity and quality of CSR disclosure provided by the five most profitable companies in Nigeria. Therefore data provided reveals the company with the most quantity of CSR disclosure based on the three dimensions which are Community, Environment and Human Resource as well as the overall level of quantity and also provides data to identify the company with the most quality of CSR disclosure based on the dimensions and overall level of CSR disclosure quality.

\section{Results}

\begin{tabular}{|c|c|c|c|c|c|c|c|c|c|}
\hline \multirow{2}{*}{$\mathrm{S} / \mathrm{N}$} & \multirow{2}{*}{$\begin{array}{l}\text { Five most } \\
\text { profitable } \\
\text { Companies } \\
\text { in Nigeria }\end{array}$} & \multicolumn{2}{|c|}{ Community } & \multicolumn{2}{|c|}{ Environment } & \multicolumn{2}{|c|}{ Human Resource } & \multirow{2}{*}{$\begin{array}{l}\text { Overall } \\
\text { Quantity } \\
\text { Score }\end{array}$} & \multirow{2}{*}{$\begin{array}{l}\text { Overall } \\
\text { Quality } \\
\text { Score }\end{array}$} \\
\hline & & Quantity & Quality & Quantity & Quality & Quantity & Quality & & \\
\hline 1 & $\begin{array}{l}\text { Dangote } \\
\text { Cement }\end{array}$ & 6.00 & 1.60 & 3.00 & 1.30 & 2.00 & 2.00 & 11.00 & 1.60 \\
\hline 2 & Nestle PLC & 1.00 & 3.00 & 3.00 & 1.60 & 2.00 & 2.00 & 9.00 & 1.10 \\
\hline 3 & $\begin{array}{l}\text { Guarantee } \\
\text { Trust Bank }\end{array}$ & 5.00 & 1.20 & 2.00 & 1.00 & 2.00 & 1.00 & 9.00 & 1.10 \\
\hline 4 & $\begin{array}{l}\text { Nigerian } \\
\text { Breweries }\end{array}$ & 2.00 & 1.50 & 2.00 & 1.00 & 1.00 & 1.00 & 5.00 & 1.20 \\
\hline 5 & $\begin{array}{l}\text { Zenith } \\
\text { Bank }\end{array}$ & 5.00 & 2.50 & 1.00 & 2.40 & 3.00 & 1.00 & 9.00 & 2.00 \\
\hline & Total Score & 19.00 & 1.96 & 11.00 & 1.46 & 10.00 & 1.40 & 33.00 & 1.40 \\
\hline
\end{tabular}

Table 3. Overall quantity and quality of CSR disclosures from the five companies in 2018 
It can be observed from Table 3 that Dangote Cement ranks number one in terms of quantity with an overall score of 11.00, from all the CSR activities disclosed under the three dimensions which constitutes Community, Environment and Human Resource. The companies with the second highest score based on quantity were Nestle PLC, GTBank and Zenith Bank with an overall score of 9.00. The company with the least score was Nigerian Breweries with an overall score of 5.00 based on quantity.

Moving on to the quality score, from Table 3 it is shown that Zenith Bank ranks number one with an overall score of " 2.00 " out of " 3.00 ". Dangote Cement is second with an overall score of "1.60" out of "3.00", while Nigerian Breweries is third in terms of quality with an overall score of " 1.20 " out of "3.00". While an overall score of "1.10" out of "3.00" makes Nestle PLC and GTBank rank number four as both of them have equal scores based on quality.

Community dimension was the most disclosed dimension by the top five most profitable companies in Nigeria, based on quantity with a total score of 19.00 disclosed CSR activities, while the Environment dimension is second with a total score of 11.00 based on quantity. Human Resource is the least disclosed dimension of CSR disclosure with a total score of 10.00 based on quantity. The overall score for the five most profitable companies in Nigeria based on quantity is 33.00 .

Furthermore, based on the quality of CSR disclosures by these five most profitable company in Nigeria, Community dimension had the highest quality of disclosures with score of " 1.96 " out of " 3.00 ". Environment dimension had a score of "1.46" out of" 3.00 " making it second in ranking based on quality. Human Resource dimension had the lowest quality of disclosures with a score of " 1.40 " out of " 3.00 ". The overall quality score for the five most profitable companies in Nigeria is " 1.40 " out of " 3.00 ".

\section{Discussion}

The central research question of this study was as follows: What is the level of CSR disclosure of the five most profitable companies in Nigeria? Findings revealed that of the three dimensions of CSR disclosure (Community dimension, Environment dimension and Human Resource dimension), Community dimension was the most disclosed dimension by the five most profitable companies in Nigeria based on quantity and quality, while the Environment dimension was the second most disclosed dimension based on quantity and quality. The Human Resource dimension was the least disclosed dimension by the five most profitable companies in Nigeria based on quantity and quality. Based on these findings, the answer to this study's central research question is that the five most profitable companies in Nigeria disclosed a lot about the different CSR activities they had undertaken in the last 12 months, but the quality of these disclosures were relatively low, with most companies providing only statements of the CSR activities they had undertaken without disclosing the amounts spent on these activities, and without providing pictorial evidences that these activities did in fact take place.

These findings have several implications: The first major implication is that these companies focused more on CSR activities benefitting stakeholders outside the company, whilst not paying as much attention to their employees who arguably are one of their most important stakeholders. It is important that these companies address this shortfall by ensuring that CSR initiatives are equally targeted at improving the welfare of their employees so as to make them more committed to the company and subsequently improving their performances.

Another implication of the findings of this study is the fact that Nigeria's most profitable companies paid little attention to the quality of their CSR disclosures in terms of providing stakeholders with the amount of money spent on accomplishing these initiatives as well as providing pictorial evidence that these initiatives were actually executed. Nigerians are generally skeptical of big business, and providing pictorial evidences of benevolent CSR activities in the community will go a long way in reducing this skepticism and improving relations between big business and the common man in Nigeria. Additionally, 
these big companies need to utilize other media besides their annual report and websites to disseminate to the public the amount of good they are giving back to the community. This improves the standing of the company in the eyes of the public and can even lead to increased patronage of their products and services; it can thus serve as a win-win for all stakeholders concerned.

\section{Conclusions}

Over the years, the Nigerian government have not been able to provide the basic needs of its citizens, which has led to much expectation from the Nigerian citizens on prosperous private companies to do so. Fortunately some of the profitable firms in Nigerian have been living up to this expectation, by practicing CSR. The study evaluated the quantity and quality of CSR disclosure, provided by the five most profitable companies in Nigeria. A content analysis of the 2018 annual reports and websites of the five most profitable firms in Nigeria was carried out. Findings revealed that these companies disclosed a lot about the different CSR activities they had undertaken in the last one year, but the quality of these disclosures were relatively low, with most firms providing only statements of the CSR activities they had undertaken without disclosing the amount spent on these activities, and without providing pictures as evidence that these activities did in fact take place.

Despite the important contributions made by this study, it was not without its limitations. Firstly, it only investigated the CSR disclosures of the five most profitable companies in Nigeria. This thus limits the generalizability of the results. Future studies can address this limitation by increasing the number of companies in the analysis. A second limitation is that only annual reports for one year were analyzed. Future studies can analyze company annual reports over several years in order to determine if the quantity and quality of CSR disclosures have improved or declined over a stated period of time.

The social contract between companies and citizens is an important one that all companies must consider carefully and try to fulfill if they have any aspirations of remaining profitable over a sustained period of time. One way companies can fulfill this contract is by engaging in CSR activities that target the most urgent needs of the citizens in the locality they operate. A second strategy is to ensure that these CSR activities were widely publicized and disseminated using both internal and external communication channels to ensure that all stakeholders are well informed of how much these companies are doing to help improve the lives of all citizens.

\section{References}

Ali, W., Frynas, J. G., \& Mahmood, Z. (2017). Determinants of corporate social responsibility (CSR) disclosure in developed and developing countries: A literature review. Corporate Social Responsibility and Environmental Management, 24(4), 273-294.

Alotaibi, K. O., \& Hussainey, K. (2016). Determinants of CSR disclosure quantity and quality: Evidence from non-financial listed firms in Saudi Arabia. International Journal of Disclosure and Governance, 13(4), 364-393.

Amodu, N. (2017). Regulation and enforcement of corporate social responsibility in corporate Nigeria. Journal of African Law, 61, 105-130.

Appuhami, R., \& Tashakor, S. (2017). The impact of audit committee characteristics on CSR disclosure: An analysis of Australian firms. Australian Accounting Review, 27(4), 400-420.

Barakat, F. S., Pérez, M. V. L., \& Ariza, L. R. (2015). Corporate social responsibility disclosure (CSRD) determinants of listed companies in Palestine (PXE) and Jordan (ASE). Review of Managerial Science, 9(4), 681-702. 
Beck, C., Frost, G., \& Jones, S. (2018). CSR disclosure and financial performance revisited: A crosscountry analysis. Australian Journal of Management, 43(4), 517-537.

Bhatia, A., \& Chander, S. (2014). Corporate social responsibility disclosure by SENSEX companies in India. Management and Labour Studies, 39(1), 1-17.

Bouten, L., Everaert, P., Van Liedekerke, L., De Moor, L., \& Christiaens, J. (2011). Corporate social responsibility reporting: A comprehensive picture? Accounting Forum, 35(3), 187-204.

Cahan, S. F., De Villiers, C., Jeter, D. C., Naiker, V., \& Van Staden, C. J. (2016). Are CSR disclosures value relevant? Cross-country evidence. European Accounting Review, 25(3), 579-611.

Chauvey, J. N., Giordano-Spring, S., Cho, C. H., \& Patten, D. M. (2015). The normativity and legitimacy of CSR disclosure: Evidence from France. Journal of Business Ethics, 130(4), 789803Advertising, 38(1), 109-122.

Cho, C. H., Michelon, G., Patten, D. M., \& Roberts, R. W. (2015). CSR disclosure: the more things change...? Accounting, Auditing \& Accountability Journal, 28(1), 14-35.

Corporate Affairs Commission (2020). Nigerian Corporate Registry. Retrieved from https://www.cac.gov.ng/

Etieyibo, E., \& Omiegbe, O. (2020). People with disabilities in the margins in Nigeria. Africa Review, $1-14$.

Farook, S., Kabir Hassan, M., \& Lanis, R. (2011). Determinants of corporate social responsibility disclosure: The case of Islamic banks. Journal of Islamic Accounting and Business Research, 2(2), 114-141.

Hassan, I. E., \& Batool, F. (2016). Voluntary CSR disclosure on company's website: an empirical evidence from Pakistan. International Journal of Learning and Intellectual Capital, 13(4), 289-301.

Hoang, T. C., Abeysekera, I., \& Ma, S. (2018). Board diversity and corporate social disclosure: evidence from Vietnam. Journal of Business Ethics, 151(3), 833-852.

Lawal, E., May, G., \& Stahl, B. (2017). The significance of corporate social disclosure for high-tech manufacturing companies: Focus on employee and community aspects of sustainable development. Corporate Social Responsibility and Environmental Management, 24(4), 295-311.

Muttakin, M. B., \& Subramaniam, N. (2015). Firm ownership and board characteristics: do they matter for corporate social responsibility disclosure of Indian companies?. Sustainability Accounting, Management and Policy Journal, 6(2), 138-165.

Noronha, C., Leung, T. C. H., \& Lei, O. I. (2015). Corporate social responsibility disclosure in Chinese railway companies: Corporate response after a major train accident. Sustainability accounting, management and policy journal, 6(4), 446-474.

Nurleni, N., \& Bandang, A. (2018). The effect of managerial and institutional ownership on corporate social responsibility disclosure. International Journal of Law and Management, 60(4), 979-987.

Olakoyenikan, O. (2019). Three companies dominate Nigeria's most profitable. Retrieved from https://businessday.ng/companies/article/three-companies-dominate-nigerias-most-profitable-in2018/

Omotoso, A. B., Daud, S. A., Okojie, L., \& Omotayo, A. O. (2020). Rural infrastructure and production efficiency of food crop farmers: Implication for rural development in Nigeria. African Journal of Science, Technology, Innovation and Development, 1-7. 
Reverte, C. (2016). Corporate social responsibility disclosure and market valuation: evidence from Spanish listed firms. Review of Managerial Science, 10(2), 411-435.

Roelofs, P. (2020). Contesting localisation in interfaith peacebuilding in northern Nigeria. Oxford Development Studies, 1-14.

Sharma, S. (2020). Websites and CSR Disclosure: An Exploratory Study of Corporate Behemoths in India. Journal of Applied Science, 32-40.

Stahl, G. K., Brewster, C. J., Collings, D. G., \& Hajro, A. (2020). Enhancing the role of human resource management in corporate sustainability and social responsibility: A multi-stakeholder, multidimensional approach to HRM. Human Resource Management Review, 30(3), 100708.

Wasiuzzaman, S., \& Wan Mohammad, W. M. (2020). Board gender diversity and transparency of environmental, social and governance disclosure: Evidence from Malaysia. Managerial and Decision Economics, 41(1), 145-156.

Weidner, K., Nakata, C., \& Zhu, Z. (2020). Sustainable innovation and the triple bottom-line: a marketbased capabilities and stakeholder perspective. Journal of Marketing Theory and Practice, 1-21. 
Mengevaluasi Pengungkapan Tanggung Jawab Sosial Perusahaan dari Perusahaan Paling Menguntungkan di Nigeria

\begin{abstract}
Abstrak
Penelitian ini mengevaluasi pengungkapan Corporate Social Responsibility (CSR) pada perusahaan-perusahaan paling menguntungkan di Nigeria, peninjauan dilakukan terhadap laporan tahunan dan situs web dari lima perusahaan paling menguntungkan di Nigeria menurut daftar kapitalisasi pasar 2018. Penelitian ini difokuskan pada kuantitas dan kualitas pengungkapan CSR, yang disediakan oleh perusahaan-perusahaan ini. Metode analisis yang digunakan adalah analisis isi. Hasil penelitian menunjukkan bahwa dari tiga dimensi yang merupakan pengungkapan komunitas, pengungkapan lingkungan, dan pengungkapan sumber daya manusia, pengungkapan komunitas merupakan dimensi yang paling banyak diungkapkan dari perusahaan-perusahaan yang paling menguntungkan di Nigeria. Temuan menunjukkan bahwa perusahaan-perusahaan ini banyak mengungkapkan tentang berbagai kegiatan CSR yang telah mereka lakukan dalam kurun waktu satu tahun, tetapi kualitas pengungkapan tersebut relatif rendah. Pengungkapan CSR harus didorong oleh pemerintah Nigeria dengan secara terbuka mengakui perusahaan yang mengungkapkan aktivitas CSR, hal ini akan memotivasi perusahaan lain untuk mempraktikkan dan mengungkapkan CSR.
\end{abstract}

Kata kunci: tanggung jawab sosial perusahaan, pengungkapan komunitas, pengungkapan lingkungan, pengungkapan sumber daya manusia, Nigeria.

\title{
Biographies of authors
}

\section{Abass Olabode Samuel}

Abass is a graduate of the Department of Entrepreneurship and Business Studies at the Federal University of Technology Minna. He successfully completed in undergraduate degree in 2019.

\section{Umaru Mustapha Zubairu}

Umaru is a senior lecturer at the Department of Entrepreneurship and Business Studies at the Federal University of Technology Minna. He obtained a PhD in accounting from the International Islamic University Malaysia in 2017.

\section{Bilkisu Abubakar}

Bilkisu is a lecturer at the Department of Business Administration, Baze University Nigeria. 